\title{
Correction: Supportive care during pediatric hematopoietic stem cell transplantation: beyond infectious diseases. A report from workshops on supportive care of the Pediatric Diseases Working Party (PDWP) of the European Society for Blood and Marrow Transplantation (EBMT)
}

Tiago Nava (D) - Marc Ansari • Jean-Hugues Dalle - Christina Diaz de Heredia (D) - Tayfun Güngör · Eugenia Trigoso • Ulrike Falkenberg - Alice Bertaina - Brenda Gibson - Andrea Jarisch - Adriana Balduzzi 1 - Halvard Boenig • Gergely Krivan - Kim Vettenranta - Toni Matic - Jochen Buechner - Krzysztof Kalwak (1) - Anita Lawitschka • Akif Yesilipek - Giovanna Lucchini - Christina Peters - Dominik Turkiewicz - Riitta Niinimäki - Tamara Diesch • Thomas Lehrnbecher • Petr Sedlacek • Daphna Hutt • Arnaud Dalissier • Jacek Wachowiak • Isaac Yaniv • Jerry Stein • Koray Yalçin • Luisa Sisinni - Marco Deiana - Marianne Ifversen · Michaela Kuhlen • Roland Meisel (1) • Shahrzad Bakhtiar · Simone Cesaro 1 - Andre Willasch $\cdot$ Selim Corbacioglu $\cdot$ Peter Bader

Published online: 20 February 2020

(c) The Author(s), under exclusive licence to Springer Nature Limited 2020

\section{Correction to: Bone Marrow Transplantation} https://doi.org/10.1038/s41409-020-0818-4

In the original article, the spelling of authors Jochen Buechner and Roland Meisel were spelt incorrectly and the affiliation for Dr Meisel was incorrect.
The correct affiliation for Dr Meisel is:

Division of Pediatric Stem Cell Therapy, Clinic for Pediatric Oncology, Hematology and Clinical Immunology, Medical Faculty, Heinrich-Heine-University, Duesseldorf, Germany This has been corrected in the XML and PDF of the original manuscript. 